\title{
REAFFIRMATION OF CONFESSIONS INADMISSIBLE UNDER MCNABB-MALLORY*
}

PoLICE interrogation ${ }^{1}$ of the criminal accused gives rise to serious problems regarding the right of the accused to avoid self-incrimination. The ultimate purpose of police interrogation is to compel confession. ${ }^{2}$ The process contemplates a confrontation, in the absence of trial-type safeguards, between the interrogator and the accused in which the representative of the state tries by force or persuasion to overcome the accused's will to resist self-incrimination."

*Killough v. United States, 315 F.2d 241 (D.C. Cir. 1962).

1. Either to challenge or to defend the need to interrogate is beyond the scope of this note; this practical requirement of the information-gathering process is assumed. For some of the stronger defenses of police interrogation, see Address by David C. Acheson, United States Attorney, District of Columbia, before the Citizen's Crime Commission of Metropolitan Washington, Dec. 10, 1962; Wickersham, The Supreme Court and Federal Criminal Procedure, 44 CoRnelr L.Q. 14, 21 (1958); Inbau, Law and Police Practice: Restrictions in the Law of Interrogation and Confessions, 52 Nw. U.L. REv. 77 (1957); Coakley, Law and Police Practice: Restrictions in the Law of Arrest, 52 Nw. U.L. REv. 2, 7 (1957); Inbau, The Confession Dilentma in the United States Supreme Court, 43 Int. L. Rev. 442 (1948); and Hearings Before the Special Subcommittee to Study Decisions of the Supreme Court of the Untited States, House Committee on the Judiciary, 85th Cong., $2 \mathrm{~d}$ Sess., ser. 12, pt. 1, at 32-44 (1958) [hereinafter cited as 1958 Hearings]. (Statement of Robert V. Murray, Chief of Police, Metropolitan Police Department.)

The need to interrogate is often recognized in judicial opinion. See, c.g., Culombe v. Connecticut, 367 U.S. 568 (1961) (opinion of Frankfurter, J.) :

[Q] uestioning is often: indispensable to crime detection. Its compelling necessity has been judicially recognized as its sufficient justification, even in a society which, like ours, stands strongly and constitutionally committed to the principle that persons accused of crime cannot be made to convict themselves out of their own mouths. . . .

But if it is once admitted that questioning of suspects is permissible, whatever reasomable means are needed to make the questioning effective must also be conceded to the police.

Id. at 571, 579.

Those who denigrate the need to interrogate or who would propose its abolition are either non-existent or timid and unprolific.

2. Inbau \& Reid, Criminal Interrogation and Confessions 140 (1962) [hercinafter cited as INBAU \& REID]. The authors do qualify this ultimate function:

A criminal interrogator should always remember that it is his function not only to obtain a confession from a guilty subject, but also to obtain one which meets the Ibid. necessary legal requirements.

3. Justice Frankfurter, in: Rogers v. Richmond, 365 U.S. 534 (1961), stated:

The attention of the trial judge should have been focused, for purposes of the Federal Constitution, on the question whether the behavior of the State's law enforcement officials was such as to overbear petitioner's will to resist and bring about confessions not freely self-determined. . . .

Id. at 544 . 
If the interrogator is able to compel a statement of guilt admissible in evidence, ${ }^{4}$ it is as if the accused has been compelled ${ }^{5}$ to testify against himself in court, in violation of his fifth amendment privilege. ${ }^{b}$ It might be argued that such compulsion occurs whenever the accused's will to deny is overcome by the force or persuasiveness of interrogation, however great or effective the resistance which preceded the final confession. Such an argument seems to reveal as "compulsive" the character of almost all confessions secured by interrogation. But courts, reviewing admissibility under due process standards, ${ }^{7}$ have found confessions to have been coerced only where interrogation was accompanied by the promise of favor or the threat of force ${ }^{8}$ - where, at the time of confession there was an unconscionable gap between the interrogator's power to elicit response and the accused's ability to exercise his right to silence. ${ }^{0}$ Because it is

4. Tricks, gimmicks and other more or less effective, more or less legitimate interrogative techniques are found in INBAU \& REID; O'HARA, Fuxdasrentals of CRIarisal I:VESTIGATION 104 (1956) (describing the time-honored "Mfutt and Jeff" technique); DrexStetn, Technics For the CrRare Investigator at 97-108 (1952); Alulbar, Interrogatio: (1951); and Kmo, Police Interrogation (1940).

5. In New York cases the phrase "testimonial compulsion" is used to point up the similarities between testimony at trial and response to police interrogation and to indicate that identical evidentiary standards are applicable to both situations. Sec, e.g., Pcople v. Meyer, 11 N.Y.2d 162, 164, 182 N.E.2d 103, 104 (1962).

6. U.S. CoNST. amend. 5. In 8 Wignore, EvIDENCE $\S 2266$, at 400-01 (MreNaughton rev. 1961) the author claims that it is "erroneous, both in history and in practice" to confuse the test of voluntariness for confessions and the privilege against self-incrimination. Cases which "blend the two into one principle" are to be "expected," but criticized. Sec, e.g., Bram v. United States, 168 U.S. 532, 543 (1897) ; and Burdeau v. MrcDowell, 256 U.S. 465, 475 (1921). But in their opinions modern judges have proved to be careless historians and heedless of Professor Wigmore's caveat. See, e.g., Spano v. New York, 360 U.S. 315 (1959) ; Blackburn v. Alabama, 361 U.S. 199 (1960). In Killough v. United States, 315 F.2d 241, 242 (D.C. Cir. 1962), the court came full circle:

[T] he rules of evidence pertaining to confessions in a federal trial have been formulated on the background of ... the Fifth Amendment, particularly its provision that no person shall be compelled in any criminal case to be a witness against himself....

These are the trends which lead treatise writers almost to capitulate. See 8 Wrassone, EvIDENCE § 2266, at 402 (McNaughton rev. 1961).

7. See, e.g., Culombe v. Connecticut, 367 U.S. 568 (1961); Leyra v. Denno, 347 U.S. 556 (1954) ; Spano v. New York, 360 U.S. 315 (1959); Blackburn v. Alabama, 361 U.S. 199 (1960) ; Ziang Sung Wan v. United States, 266 U.S. 1 (1924). See also MIcCosanch, EVIDENCE § 117-18 (1954); 3 WigMTORE, EVIDENCE § 815-67 (3d ed. 1940).

8. See, e.g., Payne v. Arkansas, 356 U.S. 560 (1958) (Police Chief said, "[T]here would be 30 or 40 people there in a few minutes that wanted to get him,' " and that, if the accused would tell the truth, the Police Chief probably could keep the mob from coming in. Id. at $565 \mathrm{n.10}$ ); and Blackburn v. Alabama, 361 U.S. 199 (1960) (Interrogation room literally filled with police officers). See generally 3 Wrgarore, EvideNCE $\$ \S 825-40$ (3d cd. 1940); InBad \& RetD.

Trickery and other forms of deception are allowed so long as they do not "induce" a "false" confession. INBAd \& REID, at 187-89; 3 Wrgarore, Evidence § 841 (3d cd. 1940); But see People v. Leyra, 302 N.Y. 353, 98 N.E.2d 553 (1951).

9. Physical torture is almost passé. For some of its archaic manifestations, see $\mathrm{MfCCOB}-$ 
founded upon this definition of coercion, the reaction of the courts has been incomplete; courts have validated non-coerced confessions despite their character as "compelled" self-incrimination. ${ }^{10}$ Moreover, the sanction attendant to a finding of coercion is likewise incomplete. Although the improperly obtained confession itself is deemed inadmissible, evidence found with its aid ${ }^{11}$ and subsequent, "voluntary," reaffirming confessions ${ }^{12}$ made in the absence of coercion are admissible despite the illegality which taints their source. Under traditional analysis, ${ }^{13}$ this material is admissible since it, as opposed to the coerced confession itself, is both probative and trustworthy. Thus, unlike current interpretation of similar fourth amendment situations, this analysis fails to consider the violence coercion does to constitutional privileges as relevant to the scope of the rule. ${ }^{14}$ There is a pragmatic edge to this response of the courts: the confession produced by interrogation of a resisting accused provides information too useful and too all-encompassing to expect interrogation to be wholly forbidden or to expect its successes to be wholly discarded. Although these existing processes may rest on shifting sand, this Note will assume the continued need for interrogation, the present incompleteless of exclusionary rules, and the courts' limited definition of compulsion; within this context, this note will examine the admissibility of reaffirmed confessions in an effort to develop standards adequate both to protect the accused from the effects of coercion and to inhibit over-reaching police conduct.

Because of a felt need to apprise the prospective criminal defendant of his rights, codes of criminal procedure, ${ }^{15}$ including the Federal Rules, ${ }^{10}$ common-

MICK, EVIDENCE $\S 109$, at 227 (1954). For some modern methods considered too gross to allow the admission of the confession, see, e.g., Columbe v. Connecticut, 367 U.S. 568 (1961) (after long interrogation accused's wife and sick child summoned and brought before accused) ; Leyra v. Denno, 347 U.S. 556 (1954) (confession by tired, drowsy accused) ; Spano v. New York, 360 U.S. 315 (1959) (accused's policeman friend playing upon the sympathies of deferdant).

10. See, e.g., Crooker v. California, 357 U.S. 433 (1958) ; Cicenia v. Lagay, 357 U.S. 504 (1958).

11. See Killough v. United States, 315 F.2d 241, 252 (D.C. Cir. 1962) (discussion of Wright, J., concurring).

12. See MCCoRMICK, EVIdence \& 114 (1954).

13. See 3 Wigmore, Evidence $\S 822$ (3d ed. 1940).

14. Compare Silverthorne Lumber Co. v. United States, 251 U.S. 385 (1920) and Nardone v. United States, 308 U.S. 338 (1939), with 8 Wigmore, Evidence $\& 2260$ (McNaughton rev. 1961).

15. See, e.g., Cal. Penal Code $\$ 849$ (1956) ; Ilt. Rev. Stat. ch. 38, $\S 660$ (1935); N.Y. Code Crra. Proc. § 165 (1958). See also Culombe v. Connecticut, 367 U.S. 568, 584 n.26 (1961) (Frankfurter, J.), for an excellent summary of cases and statutes.

16. FED. R. CRIM. P. 5, provides in pertinent part:

\section{Proceedings Before the Commissioner}

(a) Appearance before the Commissioner.

An officer making an arrest under a warrant issued upon a complaint or any person making an arrest without a warrant shall take the arrested person without unnecess sary delay before the nearest available commissioner or before any other nearby officer empowered to commit persons charged with offenses against the laws of the 
1y provide that shortly after arrest the accused is to be taken to a preliminary hearing where a judicial officer will inform him that "he is not required to make a statement and that any statement made by him may be used against him"; $; 1$ after the hearing, he may have the opportunity to post bail. ${ }^{18}$ In any event, he will pass out of the exclusive control of the police.10 In the time span between the arrest and the magistrate's warning, police interrogation is fraught with dangers of coercion..$^{20}$ Faced with the persistent interrogator, uninformed of his rights, isolated from friends and overcome by the "sinister venue"21 of the police station, the accused is most vulnerable, most likely to incriminate himself. Until 1943 state and federal law, developed under the impetus of Supreme Court decision, failed to distinguish the admissibility of confessions obtained during this period from confessions obtained during later, more pro-

United States. When a person arrested without a warrant is brought before a commissioner or other officer, a complaint shall be filed forthwith.

(b) Statement by the Commissioner.

The commissioner shall inform the defendant of the complaint against him, of his right to retain counsel and of his right to have a preliminary examination. He shall also inform the defendant that he is not required to make a statcment and that any statement made by him may be used against him. The commissioner shall allow the defendant reasonable time and opportunity to consuit counsel and shall admit the defendant to bail as provided in these rules. (Emphasis supplied.)

Compare, Advisory Committee on Rules of Criminal Procedure, Frderar Rules of Crossinal Procedure: Prelarinary Draft at 11 (1943). Restating "the present law," in view of McNabb v. United States, 318 U.S. 332 (1943), the preliminary draft of the rules included, as Rule 5(b), the following:

(b) Exclusion of Statemcent Secured in Violation of Rule

No statement made by a defendant in response to interrogation by an officer or agent of the government shall be admissible in evidence against him if the interrogation occurs while the defendant is held in custody in violation of this rule.

The clause was eliminated in Advisory Committee on Rules of Criminal Procedure, Froerns Rules of Crinstinal Procendre: Second Preltartnary Draft 10-11 (1944).

Compare, also, Committee on Rules of Practice and Procedure of the Judicial Conference of the United States, Rules of Crnmtar Procenure For the Umitred States Distruct Courts: Prelominara Draft of Proposed Asmendarents (1962), proposing to amend Rule 5(b) to include, "The commissioner shall inform the defendant ... of his right to request the assignment of counsel...."

17. FED. R. CRIAr. P. 5(b).

18. Fed. R. Crar. P. 5(b), 46.

19. See note 36 infra and accompanying text.

20. See, e.g., McNabb v. United States, 318 U.S. 332 (1943) ; Upshaw v. United States, 335 U.S. 410 (1948) ; Mallory v. United States, 354 U.S. 449 (1957) ; and Trilling v. United States, 260 F.2d 677, 690-91 (D.C. Cir. 1958) (separate opinion of Bazelon, J.).

In his concurring opinion in Killough v. United States, 315 F.2d 241 (D.C. Cir. 1962), Judge Wright stated:

[I]1legal detention [between arrest and preliminary hearing] is so potentially conducive to coercion that any confession procured during that time will be conclusively presumed involuntary.

Id. at 249.

21. Chalmers v. H. M. Advocate, [1953] Just. Cas. 66, 79 (Scot. 1959). 
tected periods in the criminal process. ${ }^{22}$ The common due process standard of voluntariness placed upon the defendant the burden of proving the promise of favor or the threat of force which would render the confession involuntary and, hence, inadmissible. ${ }^{23}$ This burden was aggravated, moreover, by the complexity of the test for the presence of coercion, namely, the totality of circumstances in the individual case. ${ }^{24}$ And such an imprecise test meant that limitations on interrogator responsibility were loosely defined, thereby making experimentation with judicial tolerance attractive to the police. ${ }^{25}$ Since interrogation at police headquarters was generally secret, ${ }^{26}$ testimony as to investigative techniques, physical or psychological coercion was limited to the accused and his adversaries. ${ }^{27}$ Given the expectable assessment of the credibility of criminal defendants as compared to policemen, the accused's difficulties in demonstrating the coerced character of his confession seemed virtually insurmountable in the very situation where coercion was most likely to occur.

In $M c N a b b$ v. United States ${ }^{28}$ the Supreme Court adopted a per se approach to the admissibility of pre-preliminary hearing confessions in the federal courts, abandoning the demonstrably unworkable voluntariness test as a judicial measure of due process. ${ }^{29} \mathrm{McNabb}$ renders inadmissible the confession which is the product of "unnecessary delay" 30 in bringing the accused before a magistrate for preliminary hearing. The Court was troubled by the previous evidentiary burden on the accused and the frequency of "third degree" techniques before preliminary hearing. The clear effect of the decision was to strip the preliminary interrogation of much of its value to police $;^{31}$ consequently, the police would

22. For an illustration of the pre-1943 approach to the confession problem, see 3 WIGMORE, EVIDENCE \$§ 815-67 (3d ed. 1940).

23. See, e.g., Ziang Sung Wan v. United States, 266 U.S. 1 (1924).

24. The case law does not lend itself to classification. At most one finds only a very general portrait of the type of accused who appeals to the sympathy of the court and a type of interrogative circumstance where "coercion" is likely to be found. Compare Crooker v. California, 357 U.S. 433 (1958), with Culombe v. Connecticut, 367 U.S. 568 (1961).

25. See generally U.S. National Commission on Law ObServance and EnforceMENT, Report on LAwLESSNESS IN LAW ENFORCEMENT (1931).

26. See, e.g., Ward v. Texas, 316 U.S. 547, 555 (1942); Chambers v. Florida, 309 U.S. 227, 231 (1940).

27. Admissions and confessions do not fall within the hearsay rule. 3 Wranone, EviDENCE § 816 (3d ed. 1940).

28. 318 U.S. 332 (1943).

29. Judicial supervision of the administration of criminal justice in the federal courts implies the duty of establishing and maintaining civilized standards of procedure and evidence. Such standards are not satisfied merely by observance of those minimal historic safeguards for securing trial by reason which are summarized as "due process of law"....

McNabb v. United States, 318 U.S. 332, 340 (1943).

30. McNabb was decided before the adoption of FED. R. CRIM. P. 5(a), but the language of federal statute then in effect requiring prompt presentation of persons arrested for preliminary examination was identical. McNabb v. United States, supra note 29.

31. The announcement of the departure of the federal courts from the "voluntariness" rule was not universally well received. See, e.g., Hearings Before Stbcommiltcc No. 2 of 
be less likely to delay the accused's appearance before a judicial officer where a cautionary statement would issue. ${ }^{32}$ Thus the thrust of the rule was as much against the actual or potential abuse of the police interrogative function as it

the House Committee on the Judiciary on H.R. 3690 (the Hobbs Bill), 78th Cong., 1st Sess., ser. 12, at 1-10 (1943) [hereinafter cited as 1943 Hearings] (statement of Edward J. Kelly, Superintendent of Police, District of Columbia) ; Inbau, The Confession Dilcmma in the United States Supreme Court, 43 ILI. L. Rev. 442 (1948).

Nor has resistance to the curtailment of police interrogation subsided. See, c.g., Drstrict of Columbia Consarissioners' Cosras. on Police Arrests for Investigation, RePORT AND ReCOMmendations (1962) [hereinafter cited as Horsky Report]. Following the recommendation of the committee, the D.C. Commissioners banned arrests for investigation, effective March 15, 1963. Washington Post, Jan. 11, 1963, p. 1. But see H.R. 1929, 88th Cong., 1st Sess. (To permit an officer or member of the Afetropolitan Police force of the District of Columbia to detain and question persons suspected of committing crimes, and to require bond in the case of certain material witnesses.)

The crime rate in Washington, D.C. is extraordinary and the subject of great public concern. Consequently, every major decision of the courts is thoroughly reported and criticized. See, Washington Post, Oct. 7, 1962, sec. A, p. 31, col. 1; Washington Post, Oct. 8, 1962, p. 14, col. 1. See also, The Christian Science Mfonitor, 1farch 9, 1963, p. 20, col. 5. A special Ford Foundation grant has been made to the American Law Institute to support a study of the rights of the accused following arrest. N.Y. Times, April 22, 1963, p. 30 , col. 1.

32. Eclecticism is apparent in MIcNabb v. United States, stpra note 29, and in Fro. $R$ CRDS. P. 5(b) ; the influence of the English practice and the Judges' Rules is striking. See Devlin, The Craminal Prosecution in England (1958). These advisory rules have no statutory bases, but are used by the English courts as guidelines for proper police conduct. For the text of the first four rules, see Rex v. Voisin, [1918] 1 K.B. 531, 539 n.3; the complete Rules are set forth in Culombe v. Connecticut, 367 U.S. 568, 595-97 nn.40-41 (1960). In the initial stage of the inquiry - "belonging solely to the administrative process"- the Federal Rule's imitation of the Judges' Rules is complete. See DEvis, op. cit. sipra at 31. Before arrest the English policeman has unfettered interrogative power. But to press the federal-English analogy beyond this point is to risk inaccuracy. The second stage of the Judges' Rules begins "when the suspect becomes the accused." Id. at 33. The caution or warning is an important element of the English scheme, but it is administered by the policeman at the time of arrest, not by a separate judicial officer, like the United States Commissioner. The English policeman, therefore, takes on a quasi-judicial capacity and is subject to judicial restraint. In the United States, the police do not have a similar function. There is no constitutional requirement obliging the police to notify an accused of the privilege against self-inerimination prior to interrogation. Comment, Prcarraigmmens Interrogation and the McNabb-Mallory Miasma; A Proposed Amendment to the Federal Rules of Criminal Procedure, 68 YALE L.J. 1003, 1036 (1959). See also Turner v. United States, 222 F.2d 926 (4th Cir. 1955); United States v. Heitner, 149 F.2d 105 (2d Cir. 1945). By the warning the English policeman declares himself the adversary of the accused. Where, according to the common law rule, a defendant can demand, as of right, the rejection of an involuntary confession; he has no such right when there has been a breach of the Judges' Rules.

[T] he judge has a discretion to admit or reject the evidence as he thinks fit; if, for example, there was only a technical breach of the rules or an excusable one, he would probably admit the evidence.

Devlin, op. cit. supra at 45. See also Brownlie, Police Questioning, Custody and Coutioning, [1960] CRDar. L. REv. (Eng.) 298, 300; Rex v. Voisin, [1918] 1 K.B. 531. Judicially to rebuke the policeman for his indiscretion; but to allow the confession or statement, might 
was in support of the constitutional rights of the accused. In Upshaze v. Unitcd States, ${ }^{33}$ where the Court tied the exclusionary rule to Rule 5 of the Federal Rules of Criminal Procedure, ${ }^{34}$ it became clear that exactly to comply with Rule 5 would be completely to eliminate the interrogative function immediately following arrest; ${ }^{35} M c N a b b$, however, provides the only sanction for noncompliance.

Where $M c N a b b$, coupled with Rule 5, is strictly followed, secret police interrogation is deterred, and the accused is protected from stress during a period in which he is particularly susceptible to coercion. More important, because the accused appears at the preliminary hearing unsullied and unbroken by coercive interrogation, the United States Commissioner's warning has its fullest impact, thus augmenting the accused's ability to resist the information-seeking process during the entire pre-trial period. Admission of initial confessions rendered subsequent to the Commission's warning presents fewer problems for a court since the accused is then out of the exclusive control of the interrogator. If the accused is released on bail, the police have no authority to force him to return to the police headquarters for further interrogation $; 3$ and, if they want

be a deterrent to future breach of the Judges' Rules. Nevertheless, it is little consolation to the defendant.

Even after initial warning the English policeman is not free to cross-examine the accused. If the accused begins a statement, the policeman, after repeating the caution, can ask a question to clarify that statement. But the warning, although essential, is not a palliative to interrogation following arrest.

Although the quasi-judicial caution is administered early in the English criminal prosccution and American judges look to the Judges' Rules as setting an extraordinarily high standard, the English practice, like the American, is not always effective in the control of illicit police activity. See Letter from English Policcmant on Use of Judges' Rules, Seructio Writings On The Law Of Evidence And Triaz 845-46 (Fryer ed. 1957); G. Williams, Questioning by the Police: Some Practical Considerations, [1960] Crns. L. Rev. (Eng.) 325, 327-28. See also Special Issue On Police Questioning, [1960] Crus. L. REv. (Eng.) 293-380.

33. 335 U.S. 410 (1948).

34. See note 16 sitpra.

35. [A] confession is inadmissible if made during illegal detention due to failure promptly to carry a prisoner before a committing magistrate, whether or not the "confession is the result of torture, physical or psychological. ..."

Upshaw v. United States, 335 U.S. 410, 413 (1948).

See also Hogan \& Snee, The McNabb-Mallory Rule: Its Rise, Rationale and Resctic, 47 Geo. L.J. 1 (1958), and Comment, Prearraignment Interrogation and the McNabbMallory Miasma: A Proposed Amendment to the Federal Rules of Criminal Procedurc, 68 YALE L.J. 1003 (1959).

But see United States v. Mitchell, 322 U.S. 65.70 (1944) (confession within minutes after arrest held admissible although accused subsequently held for eight days before arraignment), and Rothblatt \& Rothblatt, Police Interrogation: The Right to Coutsel and To Prompt Arraigmment, 27 Brooksy L. Rev. 24, 40-42 (1960) (classifying eleven exceptions to McNabb-Mallory and collecting the cases under each).

36. After preliminary hearing, FED. R. CRIM. P. 5, the accused is out of the exclusive control of the police. See 1958 Hearings, at 33, 40, 42 (statement of Robert V. Murray, Chief of Police, Metropolitan: Police Department); 1943 Hearings, at 6, 7, 10 (statement 
to ask further questions, they must do so at a place of the defendant's own choosing. ${ }^{37}$ If the accused is committed to jail, first the United States Marshal ${ }^{38}$ and then the prison warden ${ }^{30}$ is charged with his safekeeping. The

of Robert J. Barrett, Chief of Detectives, District of Columbia). If the charge is a bailable offense, and the accused can post an appearance bond, Cr. Form No. 17, Appearance Bond (Rev. 7-59), the accused is released and, thereafter, can be interrogated only by consent. But cf. United States v. Massiah, 307 F.2d 62 (2d Cir. 1962) ; Note, 76 HArv. L. Rev. 1300 (1963).

If the accused is committed, he is placed in the custody of the United States MFarshal. See Commissioner's Temporary Commitment, Form A. O. 97 (Rev. 7-1-51), which provides in pertinent part:

To: The United States Marshal of the District of

You are hereby commanded to take the custody of the above named defendant and to commit him with a certified copy of this commitment to the custodian of a place of confinement within the $\longrightarrow$ District of $\longrightarrow$ approved by the Attorney General of the United States where the defendant shall be received and safely kept until discharge in due course of law ....

The Magistrate or the United States Commissioner cannot return the accused to the custody of the police. Trilling v. United States, 260 F.2d 677, 694 (D.C. Cir. 1960) (separate opinion, dissenting in part, of Bazelon, J.) ; but see Goldsmith v. United States, 277 F.2d 335, 339 (D.C. Cir. 1958) ("[T] Me Municipal Judge ordered the appellants to be held for Grand Jury, and at the request of the police signed an order placing the men in the custody of the United States Marshal and the police, permitting police interrogation and continued investigation 'for the purpose of obtaining certain pieces of evidence, ... confronting them with the complainant and for further purpose of having them re-enact the offense'" This practice was not challenged and the conviction was upheld).

37. Once out on bail, the accused would probably not choose those places which the police consider most effective for interrogation. Compare Mfueller, The Low Relating to Police Interrogation Privileges and Limitations, 52 J. Crns. L., C. \& P.S. 2, 3 (1961), zuith INBAU \& REID at 7 (1962).

38. From the time of preliminary hearing until actual commitment, the Marshal is charged with the safekeeping of the accused. 18 U.S.C. $\$ 4086$ (1958). "Safekecping" seems mever to have been construed as to require the United States Marshal to fend off the interrogator during the interval. For an indication of the practice in the District of Columbia, in regard to interrogation during this interval, see Letter from David C. Acheson, United States Attorney, District of Columbia, to the Yale Law Joumal, Mfarch 15, 1963, on file in the Yale Law Library:

Where the commitment order commits directly to jail, there is a period that may run up to a couple of hours, in which the defendant is in temporary custody in the cellblock of the Court House, awaiting transportation to the jail. There are no restrictions, other than constitutional restrictions, upon his questioning in the cellblock. It is possible, therefore, for the interrogator to gain access to the accused during this brief interval immediately following appearance before the Commissioner.

39. See 18 U.S.C. \& 4042 (1958).

If the accused is apprehended in a district where there is no federal penal institution, he may be confined in a state prison which is under contract with the Director of the Bureau of Prisons. 18 U.S.C. $\$ \S 4002,4003$ (1958). At the state institution the United States MFarshal has the right and power to fix and govern terms and conditions of confinement. Sce Evans v. Madigan, 154 F. Supp. 913 (N.D. Cal. 1957). Presumably, the Mrarshal could determine who could have access to the accused for interrogation. Otherwise, access to the accused would be governed by the relevant state statutes. See A. Goldstein, The Stafe and 
policeman then must comply with prison regulations ${ }^{40}$ and obtain the defendant's consent to a direct confrontation before he can pursue interrogation. However ineffective any of these safeguards may be, ${ }^{41}$ the accused is to some degree made aware of his right to silence and protected from physical coercion. Hle is rendered a better match for the interrogator, and there is less chance for the use of coercive techniques to which only the accused could testify.

This structure of protection, however, is destroyed where the principle of Rule 5 is evaded. If the police delay the preliminary hearing and obtain a confession from the accused, despite awareness of the confession's inadmissibility, the confession, once given, will be hard to repress $\mathbf{4 2}^{\mathbf{2}}$ the accused's ability to resist the information seeking process will have been extraordinarily diminished. The impact of the Commissioner's warning will be much weaker than it would have been absent a prior confession, for one cannot be expected effectively to deny, even after repeated warnings, that which he has just admitted. ${ }^{43}$ Even in the absence of coercion after the preliminary hearing, a reaffirmation may be too readily achieved for a court to be at ease with the voluntariness standard which will then be applied in considering its admissibility.44

Of course, after an accused has once let the cat out of the bag by confessing, no matter what the inducement, he is never thereafter free of the psychological and practical disadvantages of having confessed. He can never get the cat back in the bag. The secret is out for good.45

The Accused: Balance of Advantage in Criminal Procedure, 69 YALE L.J. 1149, 1188 n.130 (1960).

That the police or the federal interrogator has access to the accused for further interrogation is assumed even in those studies which are most protective of the rights of the accused. See, e.g., HoRSKy REPORT 46, 63 (1962).

40. In the District of Columbia, jail regulations require the interrogator to obtain the consent of the accused prior to questioning. See Jackson v. United States, 285 F.2d 675, 677-78 (D.C. Cir. 1960) (form containing request, purpose, consent, and names of interrogators or visitors).

41. See Jackson v. United States, 285 F.2d 675 (D.C. Cir. 1960) ; Goldsmith v. United States, 277 F.2d 335 (D.C. Cir. 1960) ; Naples v. United States, 307 F.2d 418 (D.C. Cir. 1962).

42. Psychiatric scholarship does not seem to have been directed to this specific problem. Even in related areas there is little agreement among the scholars. Compare Gross, Cruminal Psychology (Kallen ed. 1911), with Reik, The Compursion To Conress ch. 5, at 254 (1959). See also Redlich, Ravitz \& Dession, Narcoanalysis and Truth, 107 AM. I. Psychiatry 586 (1951); Dession, Freedman, Donnelly \& Redlich, Drug-Induced Reve* lation and Criminal Investigation, 62 Y ALE L.J. 315 (1953).

43. See note 92 infra and accompanying text.

See also Naples v. United States, 307 F.2d 618 (D.C. Cir. 1962).

Naples when presented for preliminary hearing had received the Rule 5 warning. At the jail, the officer testifies, he had advised Naples that he need not talk to the officers. ... According to the officer, Naples said that "he had already told the rest of the policemen and he saw no reason why he wouldn't tell me."

Id. at 623 .

44. But cf. Lyons v. Oklahoma, 322 U.S. 596, 603 (1944).

45. United States v. Bayer, 331 U.S. 532, 540 (1947). 
In such a sense, a later confession always may be looked upon as fruit of the first. Deprived of the full benefits of the preliminary hearing and subject to the lingering effects of his prior admissions, the accused is unprepared psychologically to withstand further interrogation during the interval between preliminary hearing and trial.

Federal police have not been deterred from detention and interrogation during the pre-preliminary hearing period. ${ }^{46}$ This behavior is encouraged by the inadequacy of the $M c N a b b$ exclusionary rule. Although in illegal search and seizure cases ${ }^{47}$ neither evidence unlawfully obtained nor evidence shown to be the "fruit" 48 of such illegal evidence can ever be considered admissible," a similar doctrine has not been applied to the "fruit" of illegal police interrogation. ${ }^{50}$ The admissibility of evidence discovered as a result of an inadmissible confession has been virtually unchallenged $; 1$ the ground for this failure lies, perhaps, in a feeling that such evidence proves its own probative value, as the coerced confession may not, ${ }^{52}$ and that it is not as prejudicial to the defendant's case as the confession itself. ${ }^{53}$ Exclusionary rules like $M I c N a b b$, moreover, are

46. In Killough v. United States, 315 F.2d 241, $257-58$ n.5 (D.C. Cir. 1962), Burger, J., suggested that the "Suppression Doctrine"-by which he means illegal searches and seizures as well as illegal detention of the accused for purposes of obtaining a confessionhas "totally failed to achieve its stated objective," because it has not been "implemented." Implementation, for his purposes, would amount to sending a transeript of the motion to suppress to the D.C. Commissioners for proper disciplinary action. He would not, however, do anything which "punishes society as a whole for the transgressions of a poorly trained and badly motivated policeman...." (dissenting opinion).

47. See Boyd v. United States, 116 U.S. 616 (1886); Weeks v. United States, 232 U.S. 383 (1914) ; Silverthorne Lumber Co. v. United States, 251 U.S. 385 (1920). Compare Mapp v. Ohio, 367 U.S. 643 (1961).

48. The metaphor, a favorite in judicial opinion, seems about to make its solemn progress from fourth amendment to fifth amendment problems. See Jackson v. Unitcd States, 273 F.2d 521 (D.C. Cir. 1959) (per curiam) (the first Jackson case.); and Killough v. United States, 315 F.2d 241, 244 (D.C. Cir. 1962).

49. Silverthorne Lumber Co. v. United States, 251 U.S. 385 (1920); Nardone v. United States, 308 U.S. 338 (1939) ; Mapp v. Ohio, 367 U.S. 693 (1961). For an argument for limiting the operation of the MIapp rule, see Note, Mapp v. Ohio and Exclusion of Evidence Illegally Obtained by Private Parties, 72 Y ALE L.J. 1062 (1963).

50. An aversion to "Third Degree" police interrogative practices, or to their modern equivalents, has never been so strong as to penalize the police to this extent. So to hold would, indeed, amount to saying "the criminal is to go free because the constable has blundered." People v. Defore, 242 N.Y. 13, 21, 150 N.E. 585, 587 (1926) (Cardozo, J.). But the reasons for drawing up short in the case of confessions have never been articulated. One assumes that to hold the confession and all evidence gathered from it inadmissible would be too seriously to jeopardize the public interest and public safety. Compare Killough v. United States, 315 F.2d 241, 252 (D.C. Cir. 1962) (Wright, J., concurring).

51. See Killough v. United States, 315 F.2d 241, 252 (D.C. Cir. 1962) (Wright, J., coneurring).

52. See PerIman, Due Process and the Admissibility of Evidence, 64 Hanv. L. REv. 1304, 1308-09 (1951).

53. Another reason might be suggested by the way in which the court handled this secondary evidence in Killough v. United States, supra note 51, at 245. Reversing the con- 
not constitutionally compelled, but applied as a matter of policy in enforcing constitutional protections. ${ }^{54}$ However effective $M c N a b b$ 's extension to connected evidence would be as a deterrent to improper police activity, the vigorous reaction to the presently narrow rule suggests that the effect upon the information-gathering process of including within its sanctions the inadmissibility of non-confession evidence, rendering pre-preliminary hearing interrogation unavailable as a mode of investigation, would make extension intolerable and inexpedient. ${ }^{55}$ Not only has the admissibility of this secondary evidence derived from the inadmissible confession been unchallenged, but subsequent confessions preserving or reviving the primary admission of guilt are also received in evidence ${ }^{56}$ although the pragmatic need is not as strong. ${ }^{57}$ In United States $\%$. Bayer, ${ }^{58}$ the Supreme Court explicitly declined to adopt a strict exclusionary rule for reaffirmations. If the police can obtain a reaffirmation which itself satisfies the voluntariness rule, ${ }^{50}$ it will be admitted. $M c N a b b$, therefore, has al-

viction on the theory of the inadmissibility of the reaffirming confession, and remanditig the case to the District Court for new trial, the court did not feel compelled to decide the isstie of the inadmissibility of the secondary evidence. Similar trends, although inarticulate, might run throughout the cases.

54. 318 U.S. 332, 340 (1943). Cf. cases cited note 47 stipra.

55. For the extent of opposition to the restrictive character of his rule, see $1958 \mathrm{Hec}$ ings at 32-44 (statement of Robert V. Murray, Chief of Police, Metropolitan Police Department) ; 1943 Hearings at 1-10 (statement of Edward J. Kelly, Superintendent of Police, District of Columbia).

56. See Jackson v. United States, 285 F.2d 675 (D.C. Cir. 1960); Goldsmith v. United States, 277 F.2d 335 (D.C. Cir. 1960). See also McCorarck, Evidence \& 114 (1954). But see Jackson v. United States, 273 F.2d 521 (D.C. Cir. 1959); Killough v. United States, 315 F.2d 241 (D.C. Cir. 1962).

57. It is often assumed that the police and federal agents have full powers of interrogation following arrest, subject to prison and jail regulations. See notes 39 and 40 supra. In a related context some courts have classified this as a duty to investigate. United States v. Massiah, 307 F.2d 62, 66 (2d Cir. 1962). But the conceptual scheme of the Federal Rules of Criminal Procedure and McNabb-Mallory could be considered to foreclose all police interrogation following preliminary hearing. The general policy of $M \subset N a b b$ is that "the awful instruments of the criminal law cannot be entrusted to a single functionary. The come plicated process of criminal justice is therefore divided into different parts, responsibility for which is separately vested in the various participants upon whom the criminal law relies for its vindication." McNabb v. United States, 318 U.S. 332, 343 (1943). The Federal Bureau of Investigation, other investigatory officers of the federal government and the Metropolitan Police Department of the District of Columbia-all are charged with the investigation of criminal acts. Questioning everyone who might have relevant information is indispensable to the adequate performance of this duty. When sufficient information is gathered to connect a particular individual with the crime, the officer makes an arrest and the citizen becomes the accused. The accusation effects the transformation. In thcory, at least, nothing more is required of the police officer as interrogator. Interrogation after arrest has as its purpose the conviction of the defendant-something beyond crime prevention and crime detection. The prosecutor is not without means of obtaining information either from the accused directly or from the witnesses, as well as the accused, who appear before the grand jury. Cf. Dession \& Cohen, The Inquisitorial Functions of Grand Jurics, 41 Yale L.J. 687 (1932). See also Orfield, The Federal Grand Jury, 22 F.R.D، 343 (1959).

58. 331 U.S. 532 (1947).

59. See MCCoRMICK, EVIDENCE \& 114 (1954). 
ways had exposed flanks. So long as evidence or reaffirmations resulting from inadmissible confessions are admitted, complete deterrence can not be expected of the rule. But only after the last broad restatement of $M c N a b b$ by the Supreme Court in Mallory v. United States, ${ }^{60}$ did specific examples of purposeful police circumvention through the obtaining of reaffirmations appear in the courts. ${ }^{\text {BI }}$

In Jackson v. United States ${ }^{62}$ the United States Court of Appeals for the District of Columbia Circuit first met the problem of circumvention of $\Delta I C N a b b$ Mallory through the use of a reaffirming confession. During the eleven hour period between arrest and preliminary hearing, appellant Jackson orally confessed to a robbery. Immediately after the Commissioner's warning he was taken back, in the custody of the United States Marshal, to the robbery squad office where he signed a written confession which had been prepared during the interval. In a per curiam opinion, the court held the reaffirming confession inadmissible since it was neither "an independent act based upon proper counsel" nor one "occurring after time for deliberate reflection." facts were introduced which put the problem of admissibility of reaffirmations more squarely before the court. ${ }^{64}$ At preliminary hearing Jackson had had the advice of counsel; after the hearing he had been taken to the hospital where he confronted the victim and expressed his regrets about the incident; and he had received an additional judicial warning at a second hearing. Viewing the complete pattern of events, the D.C. Circuit held the reaffirming confession, taken by the investigating detectives at the jail, an independent act and therefore admissible. The fact pattern in Goldsmith $v$. United States, ${ }^{05}$ decided shortly before the second Jackson case was similar. Brief consultation with counsel, a colloquy with the victim and a reenactment of the crime were accepted as indicia of the independence of the reaffirming confession.

The District of Columbia Circuit Court was again confronted with the issue

60. 354 U.S. 449 (1957). Reference to the exclusionary rule often includes Upshaw v. United States, 335 U.S. 410 (1948), but hereinafter the rule will be cited in the shorter form, as McNabb-Mallory.

61. In Killough v. United States, 315 F.2d 241 (D.C. Cir. 1962), Judge Fahy quoted from the testimony in Naples v. United States, 307 F.2d 618, 623 (D.C. Cir. 1962), where the police officer admitted that his "only reason for going to the jail to talk to this defendant was to satisfy what might be the additional requirements in the application of the Mallory rule..."

Killough v. United States, supra at 242.

In Killough, the officer's objective was identical:

On cross examination the officer said he had read a case which indicated that a confession obtained before arraignment, although it was no good, it was all right to tall: about it after arraignment if the defendant made a reference to it or repested it.

Id. at $243 \mathrm{n} .2$.

62. 273 F.2d 521 (D.C. Cir. 1959). See Note, 70 YALE L.J. 298 (1960).

63. $273 \mathrm{~F} .2 \mathrm{~d}$ at 523.

64. Jackson v. United States, 285 F.2d 675 (D.C. Cir. 1960); see Note, 49 Gro. L.J. 618 (1961).

65. 277 F.2d 335 (D.C. Cir. 1960); see Note, 74 HArv. L. REv. 1222 (1961). 
of determining the independent nature of a second confession in Killongh $v$. United States. ${ }^{66}$ James W. Killough had reported the disappearance of his wife and arranged to meet with the District of Columbia police on October 19, 1960, to assist with an investigation. ${ }^{67}$ When he failed to keep this appointment the police proceeded independently. But Killough finally was located on October 24,1960 , taken to police headquarters at 9:30 A.M. and questioned throughout the day. $\mathrm{He}$ was arrested at 9:00 P.M. that evening. On the following day, between $12: 30$ and 1:00 P.M., he confessed to killing his wife and led the police to the city dump where he had hidden her body. After his confession was reduced to writing, he was taken to the United States Commissioner for proceedings under Rule 5 of the Federal Rules of Criminal Procedure. ${ }^{88}$ In accordance with this rule, the Commissioner informed Killough of his constitutional rights, but the actual probable cause hearing was continued to November $15,{ }^{60}$ to allow him to obtain counsel. Killough was then committed to the District of Columbia Jail. Within twenty-four hours, and before Killough had obtained counsel, the arresting officer, under the pretext of returning certain items of clothing and arranging for the disposition of Mrs. Killough's body, ${ }^{70}$ gained access to the accused. During a one-half hour conversation the officer led the accused to the subject of the earlier confession. Casually and without pressure the police liet1tenant obtained an oral reaffirmation of the earlier confession. ${ }^{71}$ Here the police technique was more subtle than that found in some cases; but for the possibility that $M c N a b b-M a l l o r y$ was circumvented, the procedures which the police liet1tenant followed in seeking information were unassailable. The police liettenant complied with the regulations of the District of Columbia Jail ${ }^{22}$ in obtaining defendant's consent prior to confrontation. He respected the restrictions of the commitment order, ${ }^{73}$ and did not attempt to remove the accused to police headquarters. Nevertheless, the integrity of McNabb-Mallory was challenged by finding a way around it. For the court in Killongh not to meet this challenge would have been to leave the police a much too attractive loophole. Of what

66. 315 F.2d 241 (D.C. Cir. 1962), reversing 193 F. Supp. 905 (D.D.C. 1961).

67. Id. at 255-57 (dissenting opinion). The statement of facts is taken from Judge Burger's dissenting opinion.

68. FED. R. CRIM. P. 5, supra note 16.

69. Killough v. United States, 315 F.2d 241, 243 (D.C. Cir. 1962).

70. Id. at 256 (dissenting opinion). On appeal, one issue before the court was the atd missibility of the coroner's testimony in regard to the discovery of the victim's body. Although Judge Wright, in his concurring opinion, would have excluded such testimony under the rule of Silverthorne Lumber Co. v. United States, 251 U.S. 385 (1920) and Nardonte v. United States, 308 U.S. 338 (1939), the Killough court, in deciding the cases on the basis of the inadmissibility of the reaffirming confession alone, passed the isste, Killough $v$. United States, sipra note 69, at 245-52.

71. Id. at 256 (dissenting opinion by Burger, J.).

[The interrogating officer] testified that Killough was "overly talkative," needed no prompting and would have continued the conversation longer if ... [the officer] had been willing to stay. Killough also requested... [ the officer] to return later to visit.

72. See note 40 supra and accompanying text.

73. See note 36 supra and accompanying text. 
consequence would it be to strike down a post-arrest confession if its total evidentiary value could be so easily resuscitated? As a deterrent to police lawlessness, McNabb-Mallory would be useless; the interrogator, in effect, would have the benefit of both the secondary evidence derived from the confession and the primary admission of guilt.

The Killough court, sitting en banc, was split five-four, with four dissents filed; the "majority opinion" holding the confession inadmissible commanded only four signatures, with Judge Wright concurring on broader grounds than his brethren cared to reach. Judge Fahy, writing for the "majority" was unwilling to meet the issues squarely. But the language of his opinion indicates an awareness that the Killough confessions raised two important problems: the accused's diminished ability to resist interrogation, ${ }^{74}$ and the concerted attempt of the police to circumvent McNabb-Mallory. ${ }^{75}$ It was this latter consideration-a desire to protect the integrity of $M C N a b b$-Mallory-which seemed to be the dominant concern of his court. As Judge Fahy wrote:

To admit [the reaffirming confession] would in substance and effect admit the earlier confessions properly held inadmissible, and thus defeat the exclusionary rule. To hold otherwise would be in reality to permit an accused to be tried without counsel, jury or court, alone with police at their headquarters or at jail. ${ }^{76}$

By its apparent reference to problems affecting the admissibility of all confessions obtained by interrogation, the passage may indicate a concern for the striking differentiation between due process standards and trial-type safeguards at trial and before trial. ${ }^{77}$ But the text is in fact directed to the narrow issue of

74. Killough v. United States, 315 F.2d 241, 243 (D.C. Cir. 1962) (referring to the irony of the magistrate's warning).

75. In his opinion Judge Fahy quoted from the record in Naples v. United States, 307 F.2d 618 (D.C. Cir. 1962), which "frankly revealed that [the later confession] was obtained for the purpose of circumventing the Mallory rule. . ." Killough v. United States, 315 F.2d 241, 242 (D.C. Cir. 1962). To quote from the record of another case to support an assertion of "circumvention" in Killough did not go unnoticed by the dissent. Id. at 255 (Burger, J., dissenting).

76. Id. at 244 .

77. The approach taken in this note is to consider the problem of a reaffirming confession withir the normal chronology of events-from illegal detention and confession, to the breakdown of the McNabb-Mallory scheme for protecting the accused and the consequent ineffectiveness of the magistrate's warning, to the establishment of standards for detcrmining the admissibility of the reaffirming confession. But rather than view the problem from arrest forward, one could consider the admissibility of the second confession by reasoning from trial backward through the pre-trial proceedings.

Commentators seem to agree that something happens to the accused at the time of arrest. See Devitu, The Crnmtarar Prosecution in England 33 passim (1958); Killough v. United States, 315 F.2d 241, 247 (D.C. Cir. 1962) (Fahy, J.). Metaphorically, arrest is a "declaration of war." DeVLIN, op. cit. supra. Or, as Judge Fahy indicates, arrest may signal a "change in the status and relationship of the parties. ..." Killough v. United States, supro at 247. But once "probable cause" has been proved or an indictment has been issued, it is evident that the government, as adversary, will pursue conviction; courts act as the arbiter 
circumvention in the $M c N a b b$ context; even then, however, there seem to be certain weaknesses in Judge Fahy's reasoning. If the police obtain a second confession through non-coercive interrogation occurring after the preliminary hearing, that confession could only be deemed improper if it is linked with the initial illegally obtained confession. And if the courts can develop meaningful standards for determining when the undesired link is present, those standards will aid them to decide the admissibility issue without need to refer to the emotionally weighted matter of circumvention. That the police, in obtaining a reaffirmation, acted properly, could not be characterized as circumvention. If the court, through the use of proper standards, found a link, the confession would be suppressed. It is only when meaningful standards have not been formulated, when there is no clear way to distinguish linked reaffirmation from unconnected confessions, that the court must face the apparent question of circumvention, as police seek to probe the boundaries of their freedom. To avoid that morass, the court must proceed, independently of McNabb-Mallory, to

of the conflict and the defendant, in theory at least, is especially protected by the constititional concepts of "due process" and the privilege against self-incrimination.

But, although conviction is no less a police goal in pre-trial interrogation, the constitutional protections-"counsel, jury and court"-and procedural safeguards of trial are not available then. Our concept of due process allows a variety of standards; "fairness" before trial is something less than "fairness" at trial. This differential has troubled others than Judge Fahy.

Depriving a person, formally charged with crime, of counsel during the period prior to trial may be more damaging than denial of counsel during the trial itself.

We do not have here mere suspects who are being secretly interrogated by the police... nor witnesses who are being questioned in secret administrative or judicial proceedings. ... This is a case of an accused, who is scheduled to be tried by a jutdge and jury, being tried in a preliminary way by the police. This is a kangaroo court procedure whereby the police produce the vital evidence in the form of a confession which is useful or necessary to obtain a conviction. They in effect deny him effective representation by counsel.

Spano v. New York, 360 U.S. 315, 325 (1959) (Douglas, J., with whom Black and Brennan, J.J., join, concurring). See also $i d$. at 327 (Stewart, J., with whom Douglas and Brennan, J.J., join, concurring).

Since counsel is the most mobile of trial safeguards, most attention has been focused upon this problem. See, e.g., People v. Di Biasi, 7 N.Y.2d 544, 166 N.E.2d 825, 200 N.Y.S. 2d 21 (1960); Post-Indictment Questioning In Absence of Counsel Violates Duc Process Requirements, 61 Colum. L. Rev. 744 (1961); People v. Waterman; 9 N.Y.2d 561, 175 N.E.2d 445, 216 N.Y.S.2d 70 (1961) ; People v. Meyer, 11 N.Y.2d 162, 182 N.E.2d 103, 227 N.Y.S.2d 427 (1962). By implication, the object seems to be to narrow the gap by judicializing all pre-trial proceedings, see, e.g., Note, Exclusion of Incompelent Evidence from Federal Grand Jury Proceedings, 72 YALE L.J. 590 (1963), or, as in the New York cases, supra, by making the presence of counsel at pre-trial interrogation indispensable to the admissibility of information gathered directly from the accused. Owing to physical and temporal limitations it is unlikely that the sanctuary of the court room can protect the accused from arrest through trial. But the concept of due process is sufficiently dynamic and flexible to allow a more thorough consideration of all post arrest police interrogation. Contpare Wolf v. Colorado, 338 U.S. 25 (1949) and Jackson v. United States, 285 F.2d 675 (D.C. Cir. 1960), with Mapp v. Ohio, 367 U.S. 643 (1961) and People v. Meyer, supra. See Perlman, Due Process and the Adnissibility of Evidence, 64 HARv. L. Rev. 1304 (1951). 
attempt the establishment of standards for determining the admissibility of confessions.

The majority in Killough not only declined to establish standards, it also implied its disapproval of those standards which seemed to be available through the decisions in Goldsmith and Jackson. Since Killough had had neither consultation with counsel nor the benefit of a lapse of time between the two confessions, Goldsmith and Jackson were distinguishable. ${ }^{78}$ But the court indicated that had Killough been squarely within the two earlier cases, it would have been willing to reconsider them. ${ }^{79}$ On the other hand, the court was willing to assume that the accused was at a psychological disadvantage after confessing before the preliminary hearing and that the Commissioner's warning had failed to overcome that disadvantage, i.e., that there. was a connection between the first and second confession. ${ }^{80}$ Thus, the court vacillated between an assumption that a valid second confession could be obtained after preliminary hearing and a conviction that awful things would happen if that confession were admissible. Although some of the language of the opinion is reminiscent of the search and seizure cases ${ }^{81}$ with their "fruit of the poisonous tree" doctrine, ${ }^{82}$ the poison in the fruit of Killough's first confession will, at some indeterminate time and under certain indeterminate circumstances, lose its toxicity.

78. Counsel had not been appointed at the time of Killough's reaffirming confession. Killough v. United States, 315 F.2d 241, 243 (D.C. Cir. 1962). The majority in Goldsmith v. United States, 277 F.2d 335 (D.C. Cir. 1960) relied upon a colloquy between the defendants and one of the persons robbed and another person in holding the reaffirming conicssion admissible. Id. at 341. Judge Fahy seized upon this as "another circumstance" distinguishing the case. Killough v. United States, supra at 244. Admittedly, this was a distinguishing factor, but Judge Fahy did not address himself to the insuperable dificulty which colloquy with the deceased victim would have presented in this case. Colloquy with a third party, at least, would be within the realm of the possible.

79. "Accordingly, neither Goldsmith nor Jackson requires admission of the jail confession in this case. Were the situation otherwise, a majority of the court, which now for the first time considers the problem en banc, would be ready to reconsider those cases." Killough v. United States, 315 F.2d 241, 244 (D.C. Cir. 1962).

The implied disapproval of the Goldsmith and Jackson standards-that the absence of counsel's advice and colloquy was sufficient to distinguish the cases, but that had those elements been present in Killough they would not necessarily have been sufficient to require the admission of the confession-is curious when read in conjunction with a later statement by the court.

[N]owhere have we said that a post-hearing confession, following one illegally procured before the hearing, must necessarily await the entry of counsel; nor do we predetermine that the passage of no amount of time could remove the taint of a confession obtained in defiance of the exclusionary rule.

Killough v. United States, supra at 246.

80. Killough v. United States, supra note 79, at 244.

81. See note 47 supra and accompanying text.

82. "The oral confession ... must be held inadmissible as the fruit of the latter."

Killough v. United States, 315 F.2d 241, 244 (D.C. Cir. 1962). Cf. Jackson v. United States, 273 F.2d 521 (D.C. Cir. 1959) (the first Jackson case), cited as authority by the court. The "fruit of the poisonous tree" metaphor was not used in Jackson. 
Judge Wright, in his concurrence, was fully willing to overrule Jackson and Goldsmith ${ }^{83}$ and employ in their stead a rebuttable presumption to supply greater protection against dependent reaffirming confessions. ${ }^{84}$ But he, like the majority, was unable to arrive at objective standards by which the second con" fession's independence could be established. ${ }^{85}$ The task he set would be unduly arduous: to rebut a presumption of continued coercion the court must consider the totality of conduct surrounding the second confession, examine the accused to estimate the rehabilitative effect of isolation from his adversaries ${ }^{80}$ and, on occasion, even invade the attorney-client privilege to determine the content of their consultations. ${ }^{87}$ In this crucial respect he took the same approach as the majority opinion. The integrity of $M c N a b b$-Mallory would be preserved by developing a subjective standard, unfortunately similar to that which the $\mathrm{Mc}$ $N a b b$-Mallory rule was created to avoid in similarly difficult fact situations. ${ }^{\text {, }}$ Arguably, after the preliminary hearing with its clear warning, ${ }^{80}$ at subjective standard would be less difficult to administer where the question presented was the admissibility of a confession rendered without the background of any prepreliminary hearing interrogation. But where there has been productive police interrogation in advance of the preliminary hearing, $M c N a b b$ vitiates the necessity for inquiry into the presence of coercion, since coercion is prestumed. ${ }^{10}$ Since there is no determination of coercion in the first instance, the tse of a

83. Killough v. United States, 315 F.2d 241, 248 (D.C. Cir. 1962).

84. Id. at 249. As to the first confession, obtained during illegal detention, Judge Wright establishes a conclusive presumption of involuntariness. Id. at 249-50. Cf. Note, 70 YALE L.J. 298, 305-06 (1960). Consequently, in every instance the Government, under Judge Wright's theory, would have to rebut the presumption of the continuing influence of presumed, not actual or determinable, coercion. The theory seems to assume that the very fict of confession and subsequent "psychological helplessness" is more devastating than actual coercive interrogative techniques. Killough v. United States, supra at 250. See also United States v. Bayer, 331 U.S. 532, 540 (1947). Similarly, Judge Wright did not think that "the bare admonition required by Rule $5(\mathrm{~b})$ is likely to convert spiritless despair to alert vigilance in a suspect whose secret is already out." Killough v. United States, supra at 250.

85. See Killough v. United States, 315 F.2d 241, 251 (D.C. Cir. 1962).

86. Ibid.

87. Ibid. Although he recognized the "intervention of counsel" as a "most important safeguard," Judge Wright demonstrated little confidence in "fleeting representation." His criticism was directed to Goldsmith v. United States, 277 F.2d 335 (D.C. Cir. 1960).

While counsel had been appointed just prior to the arraignments-apparently an attorney who happened to be in the courtroom-and while he conferred briefly with appellants, he quickly vanished from the scene. The attorney does not appear to have been even aware of the written confessions or their inadmissible character and he did not accompany the appellants when they were taken away.

Id. at 346 (Fahy, J., dissenting).

In Jackson v. United States, 285 F.2d 675 (D.C. Cir. 1960), the accused's attorney gave an express warning to his client immediately after preliminary hearing. $I d$. at $677 \mathrm{n.7}$. Contsidering the experience of the attorney and the accused's disregard of that advice, Judge Wright seems justified in his doubt as to the lasting effect of fleeting advice.

88. See notes 15-27 supra and accompanying text.

89. Fed. R. Crim. P. 5(b).

90. See note 29 supra and accompanying text. 
subjective standard is made virtually impossible-there is no basis for comparison to determine whether the hurtful effects of coercion, which has only possibly occurred, have been cured by subsequent events. And even if there were a means of comparison, the infinite variety of circumstances which would have to be considered in a subjective "totality" test seems to render such a standard extremely unworkable. The lingering effect of the "Third Degree" will depend on the comparative resiliency of different defendants. Mere confinement for a number of hours may be sufficient to compel one particular defendant to confess even without questioning; another might be able to withstand even the most brutal treatment before self-incrimination. ${ }^{91}$ In these situations either one or both might or might not be rendered perfectly capable of resisting interrogation following the Commissioner's warning at preliminary hearing. The combinations of psychologically unique individuals and subtle police interrogative methods are infinite. ${ }^{92}$ How thorough would the finding of fact have to be for the court to decide that, for a particular defendant, the ability to resist interrogation was satisfactory and the admissibility of a reaffirmation possible?

Even in Killough, the court can not fairly be said to have followed out its own suggestion of case-by-case analysis employing a subjective standard since it held the reaffirming confession inadmissible without detailed discussion of the facts of the case. ${ }^{93}$ But it seems that it should have faced the difficulties which such a rule would pose to both courts and police. In addition to creating unrealistic requirements of judicial inquiry, the use of a subjective "totality" standard takes an arguably unrealistic view of judicial decision. However much courts might protest that cases must be decided in the factual context of the instant controversy, they are inevitably guided by benchmarks established in previous cases. The six month period between illegal confession and reaffirmation in United States $v$. Bayer, ${ }^{94}$ for example, might well be used as a guideline. And that the defendants in Goldsmith and Jackson had fleeting consultation with counsel was at least sufficient to allow the court to avoid overruling the cases in Killough, and might provide standards for future cases. Furthermore, the problems which inhere in a subjective rule are not confined to the court; such a rule is filled with temptations and difficulties for the police and prosecutor. While the $M c N a b b$-Mallory rule, itself, might be considered a harsh and unreasonable obstacle to efficient police administration, ${ }^{05}$ it is straightfor-

91. For comments upon the impact of extended interrogation and individual reaction, see generally Hearings On Communist Interrogation, Indoctrination and Exploitation of Anerican Military and Civilian Prisoners Before the Permanent Subeommitter on Iniestigations of the Senate Committee on Government Operations, 84th Cong., 2d Sess. (1956).

92. Compare English \& French, Introduction to Psychlatry 232-91 (2d ed. 1957), with INBAU \& REID 21-116.

93. The oral confession obtained in this case at the jail so soon after the illegally procured and inadmissible confessions must be held inadmissible as the fruit of the latter.

Killough v. United States, 315 F.2d 241, 244 (D.C. Cir. 1962).

94. 331 U.S. 532 (1947).

95. See note 31 supra. 
ward and relatively clear. If the arresting officer detains the accused for questioning before preliminary hearing he can be sure that any resulting confession, the most attractive product which he can obtain from his interrogation, is subject to challenge. ${ }^{90}$ And, although this rule is not wholly self-applying, it is sufficiently clear to allow nonjudicial application and to deter to some degree the willful detention of the accused following arrest. Nevertheless, such clarity of command is completely lacking in the Killough opinions. Subjective, undefined rules are more conducive to further experimentation in circumvention than to deterrence of illegal activity - a result exactly opposite from that which the court intended and one which weakens McNabb-Mallory as well as the reaffirmation rule. If a twenty-four hour interval between confessions is too short, thirty-six hours and a brief conversation with counsel might be adequate to secure an admissible reaffirmation. So goes the police interrogator's parlor game which the court fails to discourage.

In view of these difficulties, which are implicit in the subjective rule of Killough, a single, objective standard for determining the admissibility of a reaffirming confession may offer the best solution to the problems of police circumvention of $M c N a b b-M a l l o r y$ and the debilitating effect of confessions during a period of illegal detention. ${ }^{97}$ Such a single-standard rule, limited in effect to reaffirmation situations, ${ }^{98}$ would be independent of Rule 5 of the Federal Rules of Criminal Procedure. ${ }^{99}$ The single standard-a signal, objectively ascertainable event, easily identifiable-should indicate the complete severance of the initial and subsequent confessions and an ability to cope with interrogative techniques substantially equal to that which the accused would have possessed had he not confessed prior to preliminary hearing. Three possible events or circumstances might provide such a single-standard rule: a minimum time interval between confessions; a specific warning by magistrate or counsel directed to the admissibility of previous confessions; and the presence of magistrate or counsel at any post-hearing interrogation.

96. See Mallory v. United States, 354 U.S. 449 (1957). But see Rothblatt \& Rothblatt, Police Interrogation: The Right to Connsel and to Prompt Arraignment, 27 Brookswn I. REv. 24, 40-42 (1960), for the classification of exceptions to Mallory; sce, c.g., United States v. Mitchell, 322 U.S. 65 (1944); Sutton v. United States, 267 F.2d 271 (4th Cir. 1959) ; Heideman v. United States, 259 F.2d 943 (D.C. Cir. 1958) ; Porter v. United States, 258 F.2d 685 (D.C. Cir. 1958) ; Metoyer v. United States, 250 F.2d 30 (D.C. Cir. 1957); United States v. Leviton, 193 F.2d 848 (2d Cir. 1951). Cf. United States v. Carignan, 342 U.S. 36 (1951).

97. To overrule United States v. Bayer, 331 U.S. 532 (1947) and to establish a strict

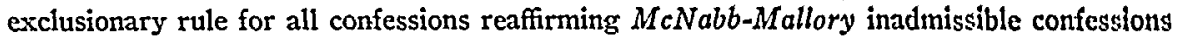
would be the most direct solution. On the assumption that there may, occasionally, be a genuinely independent reaffirming confession, however, such a rule would be extraordintrily" harsh. To discipline the police while protecting the accused can, it seems, be accomplished through other means.

One authority would avoid the problems of establishing a viable standard by holding inadmissible in evidence any confession repudiated by the accused in court. Rogge, Book Review, 76 HARv. L. Rev. 1521 (1963).

98. See note 113 infra.

99. See note 16 sipra. 
Although courts might find the first two circumstances more closely allied with the case law, these events do not necessarily assure the restoration of the accused's former ability to resist. A reasonably short, specific time interval between the two confessions-one week, a month or six months-would afford objectivity, but it might well fail, in the ordinary case, ${ }^{100}$ to offer sufficient assurance of rehabilitation. Moreover, weeks or months of "recuperation" might, in a moment, be completely destroyed either by innuendo or by an overt reminder of guilt and prior confession. The fact of prior conversation with counsel, emphasized in both Goldsmith and Jackson, or with a magistrate informed of the confession, discussed by Judge Wright in Killough, ${ }^{101}$ represents another possibility. But fleeting conversation with counsel, however emphatic he might be in his instructions to his client, is no guarantee that the accused is prepared to withstand further interrogation or make a decision to plead guilty only with a view to his best interests. ${ }^{102}$ The same objection seems to lessen the advisability of a proposed standard dependent upon warning from the magistrate. Although an official warning might seem to have more impact, there are additional impediments to judging admissibility on the basis of a magistrate's warning. The lingering effect of the first confession may not be removed by the magistrate's warnings, even if they are extraordinary; the magistrate will be unable to inform the accused conclusively as to the admissibility of his first confession. ${ }^{103}$ To receive the magistrate's warning, moreover, the accused would have to admit the fact of prior confession to a judicial officer, an admission which would necessarily have a severe psychological impact, probably veakening rather than strengthening his future resistance. Finally, as is the case for both of these suggested events, the magistrate's warning not only fails to justify a decision that the "link" has been destroyed, but also renders no assistance in evaluating the impact of interrogative techniques in obtaining the second confession.

100. See note 92 supra and accompanying text.

101. Killough v. United States, 315 F.2d 241, 250 (D.C. Cir. 1962).

102. See Jackson v. United States, 285 F.2d 675, 677 n.7 (D.C. Cir. 1960).

103. It has been suggested that accused's ignorance of the inadmissibility of a confession made during illegal detention is the source of the weakness in the commissioner's warning. In the terms of United States v. Bayer, 331 U.S. 532, 540 (1947), the warning does nothing to put the "cat back in the bag." As a remedy to this situation, it has been suggested that the accused should be told-either by the interrogator himself or by the commissioner-that the first confessiom is inadmissible. Note, 26 TExAs L. REv. 536, 538 (1948); MCCORAICK, EVIDENCE § 114, at 237 (1954). But the determination of what interrogation is legal and what is illegal is almost impossible at this stage. See supra note 97. And, as Judge Wright stated in Killough v. United States, 315 F.2d 241, 250 (D.C. Cir. 1962), "the magistrate is in no position to give such unequivocal assurance" that the carlier confession is inadmissible.

But the procedure envisioned here falls short of a determination of the admissibility of the confession. Rather, the magistrate would ask the accused if he had confessed before preliminary hearing. If the answer were in the affirmative, the magistrate would then proceed with an extraordinary warning-that it might be possible that the pre-preliminary hearing confession would be inadmissible and that the accused should, in subsequent interrogation, be exceedingly cautious in his statements to the police. 
The third suggestion, that counsel or magistrate be present at any post-hearing interrogation, seems a more radical, but more hopeful suggestion. It would insure, as a condition of holding a confession admissible, that there is an externalized reminder of the need for caution with the accused at the time of assault upon his resistance. Presence, rather than mere advice, becomes the objective prerequisite to admissibility. Indeed, what the accused, already stibjected to interrogation, needs is an agent or a buffer between himself and interogator rather than a mere remembrance of previous warning. A requirement that a magistrate be present could validly be opposed as disruptive of judicial schedules, a duplication of the effort of arraignment, and an approximation of inquisitorial jurisprudence unseemly for our legal system. ${ }^{104}$ These objections and similar objections cannot, however, be raised to the presence of a lawyer. Only inhibition of police interrogation seems a relevant complaint ;0s but that is exactly what is intended. ${ }^{106}$ By experience and perspective, informed coun-

104. See, e.g., Watts v. Indiana, 338 U.S. 49, 54 (1949).

105. See Spano v. New York, 360 U.S. 315 (1959).

106. The inhibition of the interrogative activities of the Metropolitan Police of the District of Columbia and federal investigative officers, generally, is the primary objective. For a study of the District of Columbia police practices in a related area, sec Honsky REPORT (1962). For more general comments, with specific reference to police practices in the State of California, see Barrett, Police Practices and the Lazw-From Arrest to Rilcasc or Charge, 50 CaLrf. L. Rev. 11 (1962).

In federal criminal matters, United States Attorneys seem rarely to interrogate the accused. In response to a questionnaire regarding their practices, one United States Attorney said that he and his assistants "seldom, if ever, question the accused following preliminary hearing." One said, "We . . . avoid it as a bad practice." Another replied,

We never interview subjects under arrest at any time, except where a co-defendant has plead [sic] guilty and will testify in behalf of the government at the trial of the other defendant.

Another replied,

As a general practice neither I nor any of my assistants question an accused following or prior to a preliminary hearing.

The bulk of the replies, however, indicated a practice of deferring to the federal investigative agencies in all matters of interrogation.

If counsel has been either retained or appointed, the replies indicate an attempt on the part of the United States Attorney to direct the federal investigatory agent to interrogate the accused either in the presence of counsel or, at least, with his consent. Some of the replies on this point were as follows:

If counsel has been retained or appointed, questioning of the accused is always conducted in the presence of such counsel. [No distinction was made between the fcderal investigator and the United States Attorney.]

Federal agents do interview the accused after arrest. If counsel is retained or appointed, the agents are directed to contact the attorney before an interview is undertaken.

In cases where counsel has been retained we have no contact whatsoever with the accused and any interrogation or other matters are conducted by the investigating agencies with the consent of or in the presence of counsel for the defense.

If the accused is represented by counsel, this office arranges for the accuscd to confer 
sel ${ }^{107}$ could be expected to restrain the police in the use of coercive, deceptive or subtle interrogative techniques; he would be able to assess the merits of the case to determine, with a view to the facts arising from his previous conversation with the accused, what facts should be denied and what should be admitted. ${ }^{108}$ With counsel present, therefore, courts could be assured that if the accused were to reaffirm his first confession, or, in any way, respond to questions, he would do so after a balance had been created between the power of the interrogator to induce the reaffirming confession and the accused's ability to resist self-incrimination. Just as the Commissioner's warning is compelled by $M c N a b b$-Mallory to prepare the unsullied and unbroken defendant for further questioning; so the presence of counsel is needed to prepare the victim of actual or presumptive police coercion for further interrogation.

Reaffirmation is possible under such a rule-even though it is less likely to occur. To require the presence of counsel as a prerequisite to valid reaffirmation might possibly bar "any admissions except where the accused is advised and prepared to enter a guilty plea."109 Arguably, however, there is a distinct similarity between a confession given at this stage of the criminal process, and a guilty plea. ${ }^{110} \mathrm{~A}$ defendant is not required to plead to a felony unless he has

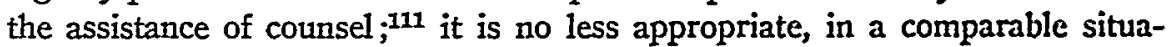
tion, to afford a similar advantage to one whose rights have been abused by illicit police activity. Presumably, the police have proved "probable cause" and have all of the information which they gained from the first confession; if so,

with such counsel prior to questioning by Government agents; if for any reason such conference cannot be accomplished, permission of defense counsel is secured prior to questioning by Government agents.

Letters from United States Attorneys to the Yale Law Journal, April-1fay, 1963, on file in the Yale Law Library.

107. Since it is the police who know what information was obtained during a period of illegal detention, they could be given the burden of seeking the reaffirming confession in the presence of counsel. But counsel, at this early stage, would need information as to what statements were made as well as other information important to the defense. Even with such a limited application; the proposed rule for admissible reaffirming confessions might strengthen the argument for extended discovery in criminal cases. Sce A. Goldstein, The State and the Accused: Balance of Advantage in Criminal Procedure, 69 YALE L.J. 1149, 1172-98 (1960); Louisell, Criminal Discovery: Dilemma Real or Apparent?, 49 Causf. I. Rev. 56 (1961); Louisell, The Theory of Criminal Discovery and the Practice of Criminal Law, 14 VAND. L. REv. 921 (1961); Developments in the Law-Discovery, 74 HaRv. L. Rev. 940, 1051-63 (1961).

108. See Special Conas. of the Ass'n of the Bar of the City of New York, EQUAL JUSTICE FOR THE ACCUSED 35 (1959).

109. Killough v. United States, 315 F.2d 241, 258 (D.C. Cir. 1962) (dissenting opinion).

110. See 3 Wigrrore, EVIDENCE $\$ \$ 816,821$ (3d ed. 1940).

111. See Comment, 68 YaIe L.J. 1003, 1004 n.2 (1959). On right to counsel, see generally Beaney, The Right to Counser in Axrericar Courts (1955); Douglas, The Right to Counsel-A Foreword, 45 MInN. L. Rev. 693 (1961); Beaney, Right to Counsel Before Arraignment, 45 MINN. L. REv. 771 (1961); Hearings Before the Subcommittee No. 2 on Representation for Indigent Defendants in the Federal Courts of the Honse Committee on the Judiciary, 86th Cong., 1st Sess., ser. 13 (1959). 
the need to interrogate is no longer so pressing, ${ }^{112}$ and it is then even more reasonable to reduce the likelihood of an attempt to profit from a former indiscretion. A similar approach has in fact been adopted by the New York courts in recent years in dealing with the right to presence of counsel generally. ${ }^{113}$ In direct response to Supreme Court dicta in Spano v. New York, ${ }^{114}$ in which the Court held inadmissible a confession resulting from a prolonged and

112. People v. Waterman, 9 N.Y.2d 561, 565, 175 N.E.2d 445, 447, 216 N.Y.S.2d 70, 74 (1961).

113. In these cases the New York courts refused to limit their consideration to a specific class of cases; their opinions bear directly upon the indispensability of counsel in post arrest or post indictment interrogation or in any situation where the prosecution secks information from the accused. In People v. Di Biasi, 7 N.Y.2d 544, 166 N.E.2d 825, 200 N.Y.S.2d 21 (1960) ; Note, 61 Coluns. L. Rev. 744 (1961), the New York Court of Appeals held that, where a defendant was questioned after indictment and surrender for arraignment in the absence of his attorney, incriminating statements made during that period were inadmissible in evidence.

In People v. Waterman, 9 N.Y.2d 561, 175 N.E.2d 445, 216 N.Y.S.2d 70 (1961), the argument of Di Biasi was pursued one step further:

The constitutional and statutory right of a defendant to the assistance of counsel at every stage of a criminal cause ... . is limited neither to capital cases ... nor to the situation where the defendant already has an attorney. The constitutional guaranteo "includes a reasonable time to obtain counsel." [sic].

People v. Waterman, 9 N.Y.2d 561, 565, 175 N.E.2d 445, 447, 216 N.Y.S.2d 70, 74 (1961).

As to the need to interrogate, Judge Fuld reasoned:

Since the finding of the indictment presumably imports that the People have legally sufficient evidence of the defendant's guilt of the crime charged ...., the necessities of appropriate police investigation. "to solve a crime, or even to absolve a suspect" cannot be urged as justification for any subsequent questioning of the defendant.

Ibid.; see note 57 supra.

The overriding concept in both cases is the principle of right to counsel and one's frecdom from "testimonial compulsion:" The same concept was again applied in the third caso in the series, People v. Meyer, 11 N.Y.2d 162, 182 N.E.2d 103, 227 N.Y.S.2d 427 (1962), but the rights in question were pushed back from the indictment stage to the time of arrest and arraignment, N.Y. CODE CRIM. P. $\$ 165$, or, in terms of the Federal Rules of Criminal Procedure, to preliminary hearing. FED. R. CRIM. P. 5(a). In Meyer voluntary, unsolicited statements made by an accused to a police officer after arraignment and before indictment were held inadmissible. The defendant had not requested counsel, nor had cotnsel becn appointed at the time the challenged statement was made. Judge Dye, writing the court's opinion, stated:

An arraignment after an arrest must be deemed the first stage of a criminal proceeding ... especially when, as here, the accused has been held for the Grand Jury, with fixation of bail. ... In reason and logic the admissibility into evidence of a postarraignment statement should not be treated any differently than a post indictment statement. A statement so taken necessarily impinges on the fundamentals of protection against testimonial compulsion, since the jury might well accord it weight beyond its worth to reach a verdict of guilty. While an accused may waive a fundamental right, he did not do so here, nor is he estopped because he had made no request when informed of his rights.

People v. Meyer, 11 N.Y.2d 162, 164, 182 N.E.2d 103, 104, 227 N.Y.S.2d 427, 428 (1962).

114. 360 U.S. 315 (1959). 
arduous interrogation, the New York courts have attacked the problem of postarrest interrogation in terms of the right to presence of counsel during the trial and investigation process. And this right has been extended, to its fullest extent, backwards from the trial through indictment to arraignment-the first pleading of the people.

Despite these seeming advantages of presence of counsel, and the experience of the New York courts, it might be argued that the presence of counsel during pre-trial interrogation-even in the limited number of cases in which illicit confessions are obtained-will be too great a clog in the prosecutorial machinery. But it is not necessary for counsel to play a role as active as he plays at trial. He would have the right to advise, but not direct, silence of him from whom the police may seek, but not compel, speech. Counsel need not have a formal role: his presence alone will restrain police coercion and encourage voluntary resistance. If, in fact, the accused is overcome by a "terrible sense of guilt" 115 and, voluntarily, wants to unburden himself by confessing to the crime, he is not estopped by this rule, and could not be silenced by counsel. If the defendant is loquacious, flaunting his crime before a cellmate or confiding in a third party-either of whom could testify to the confession-he falls outside the rule. It is not this relationship which is to be controlled; the balance to be established is that between the accused and the police. If, of course, the third party were the agent of the interrogator or the prosecutor, the sanction of the rule would apply. ${ }^{116}$ Skillfully planting and, possibly, instructing, a non-police interrogator with the accused can be at least as effective as a direct confrontation of the accused and his adversary. ${ }^{117}$ Nor need the rule make impossible the interrogation of defendants who refuse to retain, or to request the appointment of, counsel. If they come to this decision, after a reasonable time for consideration of this problem and after having been informed of their rights, their deliberate action could be considered a waiver of the rule.

Compared with the voluntariness rule or that of the Killongh court, to insist upon the presence of counsel as a prerequisite to the admissibility of a postpreliminary hearing reaffirmation of an illegal confession might pose even more difficult problems for the court were it not for the trend towards the earlier appointment of counsel in indigent cases. ${ }^{118}$ Otherwise, the impecunious accused essentially would be immune from reaffirmation, for inability to retain counsel cannot be equated with waiver of the right to counsel. ${ }^{110}$ In federal criminal procedure, the right to counsel has not been held specifically to attach at the time of preliminary hearing. ${ }^{120}$ The indigent criminal defendant cannot demand coun-

115. Killough v. United States, 315 F.2d 241, 257 (D.C. Cir. 1962) (Burger, J, dissenting).

116. But see United States v. Massiah, 307 F.2d 62 (2d Cir. 1962), criticized in 76 HARv. L. REv. 1300 (1963).

117. United States v. Massiah, 307 F.2d 62 (2d Cir. 1962).

118. Cf. Gideon v. Wainwright, 372 U.S. 335 (1963).

119. Johnsor v. Zerbst, 304 U.S. 458 (1938).

120. Burall v. Johnston, 53 F. Supp. 126, 129 (N.D. Cal. 1943), affd, 146 F.2d 230 (9th Cir. 1944). But compare, Crooker v, California, 357 U.S. 433 (1958), wilh Ciccnia v. Lagay, 357 U.S. 504 (1958). 
sel until he is required to plead to the charge. ${ }^{121}$ But the policy of earlier representation is being pursued in other ways. In the Preliminary Draft of Prom posed Amendments to the Rules of Criminal Procedure for the United States District Courts, ${ }^{122}$ the District of Columbia Legal Aid Act of 1960, ${ }^{123}$ and a similar bill now pending in both the House ${ }^{124}$ and the Senate, ${ }^{125}$ an evolving federal policy of early representation is taking clear shape. Counsel is to be appointed in all federal cases "within a reasonable time after . . . request ;" in the District of Columbia, he is to be available for all criminal proceedings potertially involving penitentiary sentences, including appearances before the United States Commissioner. ${ }^{127}$ If counsel is available for general advice and consultation at preliminary hearing and throughout the pre-trial and trial stages of the criminal process, it does not seem unreasonable to insist upon his presence during what may be the most critical of all times, the time of the reaffirmation of a confession produced, in the first instance, by improper interrogation. ${ }^{128}$

121. Johnson v. Zerbst, 304 U.S. 458 (1938); FED. R. CrIM. P. 44.

122. Commitiee on Rules of Practice and Procedure of the Judicial Confenence: of the United States, Rules of Criminal Procedure for the United Stutes Distict Courts: Preliminary Draft of Proposed Amendments Rule 44, at 25 (1962).

123. District of Columbia Legal Aid Act, 74 Stat. 229 (1960), D.C. Code $\$ 2-2202$ (1962).

124. H.R. 4816, 88th Cong., 1st Sess. (1963). See N.Y. Times, June 6, 1963, p. 31, col. 6.

125. S. 1057, 88th Cong., 1st Sess. (1963).

126. See Proposed Rule 44, supra note 120.

127. District of Columbia Legal Aid Act, 74 Stat. 229 (1960), D.C. Code $\$ 2.2202$ (1962).

128. Spano v. New York, 360 U.S. 315, 325 (1959) (Douglas, J., concurring). 